\title{
FINANCIAL LITERACY AMONG MALAY SOCIETY IN THE RIVERSIDE AREA OF CENTRAL KALIMANTAN
}

\author{
Alfina Rahmatia \\ Institut Agama Islam Negeri Palangkaraya \\ rahmatiaalfina@gmail.com \\ Diterima 16 Juni 2019 | Direview 23 Juni 2019 | Diterbitkan 28 Desember 2019

\begin{abstract}
Abstrak
Tujuan utama dari penelitian ini adalah untuk mengidentifikasi dan menganalisis tingkat kesadaran terhadap literasi keuangan di antara masyarakat Melayu di daerah tepi sungai melalui studi kasus di Desa Tanjung Putri, Kalimantan Tengah. Data primer yang digunakan dalam penelitian ini dikumpulkan dari kuesioner dan wawancara. Penelitian ini menggunakan regresi logistik biner menggunakan aplikasi SPSS, sedangkan set data wawancara menggunakan analisis deskriptif. Hasil penelitian menunjukkan bahwa jenis kelamin, pendapatan per bulan dan latar belakang pendidikan tidak berpengaruh positif signifikan terhadap tingkat kesadaran literasi keuangan di masyarakat Desa Tanjung Putri. Ini terjadi karena pengalaman masa lalu tentang literasi keuangan.
\end{abstract}

Kata kunci: Kesadaran, literasi kenangan, masyarakat Melayu

\begin{abstract}
The main objective of this study is to identify and analyze the awareness level to financial literacy among Malay society in the riverside area with a case study in Tanjung Putri Village, Central Kalimantan. Primary datas used in this study are collected from questionnaire and interview. The study uses binary logistic regression using SPSS application, whereas the interview datas use descriptive analysis. The result shows that gender, income per month and education background has no positive significant effect to the awareness level of financial literacy in Tanjung Putri Village society. These are happen because of the past experience about financial literacy.
\end{abstract}

Keywords: Awareness, financial literacy, Malay society 


\section{Introduction}

Financial inclusive terms has been discussed in Indonesia since 2008 after the economic crisis occurred in Indonesia. The definition of financial inclusive itself does not exist yet, though various institutions try to define it. One of them is from the Reserve Bank of India (RBI) which propose the definition for it is the process of ensuring access to appropriate financial products and services needed by all sections of the society in general and vulnerable groups such as worker sections and low income groups in particular at an affordable cost in a fair and transparent manner by regulated mainstream institutional players.

In Indonesia, financial inclusive policies have been drafted in the 2016 Regulation Financial Services Authority in 2016 on the chapter improving literacy and financial inclusion in the financial services sector to consumers and or community. In chapter one, article 1 , on seventh paragraph, says that financial inclusive is the availability of access for the public to take advantage of the products and or financial services in the financial services institutions according to the needs and capabilities in order to realize prosperity.

In developing financial inclusive, Financial Services Authority and Bank Indonesia have an important role inside. That is why the national strategy for the development of financial inclusive is held. It aims to encourage better coordination, to continue and expand existing initiatives, identify the obstacles, commit and encourage breakthroughs. Similarly, the Bank Indonesia socializes financial inclusive program, establishes cooperation with relevant stakeholders outside Bank Indonesia, implements financial inclusive activities, and evaluates program of financial inclusive activities.

Based on the strategies described above which knowledge of financial inclusive is still very low in the society and it needs to be improved. By doing so, the conducted training assistance to the output quality can be maintained. Besides holding training program, which is socialization, local governments also need to cooperate with the banks and the Financial Services Authority to expand the access of society financial services. ${ }^{1}$

The presence of Islamic system in the financial institution gives a new color and new shades. Islamic economic system is present at a crossroads, and

\footnotetext{
1 Ahmad Ma'ruf and Tasya Desiyana, "LITERASI KEUANGAN PELAKU EKONOMI RAKYAT," Buletin Ekonomi, no. 2 (2015): 8.
} 
shows its existence among the secular former economic systems. ${ }^{2}$ The economic crisis in Indonesia on 1998 can be an evidence, when all the conventional banks were bankrupt and even suffered from economic downturn, banks with the Islamic system stayed firm without being effected by the crisis. This incident drew public attention, even until now. FSA head of department of Islamic Banking, Ahmad Buchori, said that the development of Islamic banking in 2016 increased better than 2015. Besides the historical factors, another thing that makes Islamic economic system became the center of attention at this time is a characteristic that is offered in the Islamic economic system itself, such as the sharing system that removes interest. Interest often becomes fear for lenders of capital since those who are rich get richer and the poor get poorer.

Talking about financial inclusive, it is closely related to financial literacy. Financial literacy does not exist in any subjects within all levels of education in Indonesia, whereas it is considered important. Therefore, a person's education does not guarantee the persons skill in planning and managing his finances. According to Robert T. Kiyosaki, financial literacy is a basic ability to read and understand financial statements and to control cash flow (cash flow). Each person should know how the financial planning of the income he has. One of the part is to know the income and outcome, as well as to avoid unexpected things in the future. These unexpected things, such as early retirement or bad debt. Many people have to realize the importance of financial literacy, but still lack of knowledge and understanding of how to plan and manage both personal and household finances.

The research conducted by Deerajen Ramasawm, Savila Thapermall, S. Anoop Dowlut and Mootooganaen Ramen entitled "A Study of the Level of Awareness of Financial Literacy among Management" indicates that most students have a medium level of knowledge and skills in financial literacy and in savings and borrowings. Based on the study, it was found that age, gender, language, race and income level do not have an impact on the level of financial literacy. ${ }^{3}$ Next, the research conducted by Noor Azizah Shaari, Nurfadhilah Abu Hasan, Ramesh Kumar Moona Haji Mohamed, Mior Ahmad Jafri Md Sabri entitled "Financial Literacy: A Study Among The University" indicates

\footnotetext{
2 Muqorobin Muqorobin, "Rethinking Woman Participation in Development," IQTISAD Journal of Islamic Economics (1999): 45-57.

${ }^{3}$ Deerajen Ramasawmy et al., "A Study of the Level of Awareness of Financial Literacy among Management Undergraduates" (2013): 13.
} 
that the spending habit and year of study have a positive relationship with the financial literacy, whereby the age and gender are negatively associated with the financial literacy. ${ }^{4}$ Then, the research conducted by Bharat Singh Thapa and Raj Surendra Nepal entitled "Financial Literacy in Nepal: A Survey Analysis from College" indicates that most of the students have a basic level of financial knowledge but they lack in understanding of credit, taxes, share market, financial statement and insurance. ${ }^{5}$

In this study, the researcher will conduct case study in the Tanjung Putri village, South Arut District, West Kotawaringin Regency, Central Kalimantan. Tanjung Putri is one of the riverside areas and also remote area decided by the government of West Kotawaringin regency. Tanjung Putri is far away from the central government, it has lack of existing financial institutions. As it was broadcasted in Borneo-News, there are eight villages that are still left behind in all aspects, for example are infrastructure, education and healthcare, including financial aspect were many moneylenders are still in high number, which cause the society prefere to get loan from moneylenders rather that corporation. Such event shows that financial literacy level in Tanjung Putri is still low. In this case, the Islamic financial institution is able to be the best solution for the problem because the system that is applied in Islamic economic make a person wiser in selecting a financial product. ${ }^{6}$ Moreover, Malay society has a high religion value and integrity. ${ }^{7}$

Based on the elaboration above, as an effort to introduce Islamic financial institutions to support financial literacy in Indonesia, it is not immediately socialized or established, for example BMT (Baitul Maal wa Tamwil). However, the researcher will examine the level of financial literacy; low, medium, or high. For this reason, in this study, the researcher chooses the title "Financial Literacy Among Malay Society in The Riverside Area of Central Kalimantan".

4 Noor Azizah Shaari and Nurfadhilah Abu Hasan, "FINANCIAL LITERACY: A STUDY AMONG THE UNIVERSITY STUDENTS” 5, no. 2 (2013): 21.

${ }^{5}$ Bharat Singh Thapa and Surendra Raj Nepal, "Financial Literacy in Nepal: A Survey Analysis from College Students,” NRB Economic Review 27, no. 1 (2015): 49-74.

${ }^{6}$ Ahmad Mahadzir, "Why Islamic Financial Literacy Is Important.," in Personal Money, Islamic Financial Planning, 2010, 48.

${ }^{7}$ Siti Nasilah and Anggia Kargenti Evanurul M, "Integrasi Diri Sebagai Konsep Sehat Mental Orang Melayu Riau,” Jurnal Psikologi 11, no. 1 (April 13, 2016): 37-48. 


\section{Method}

The data used in this study is primary data taken directly from the location to be examined. This study uses mixed method, means that the research is mixed between quantitative and qualitative method. There are three basic mixed method design; convergent parallel mixed method, explanatory sequential mixed method, and exploratory sequential mixed method.

To take sample for questionnaire, the researcher will use random sampling methods. Random sampling method is the sampling process that everyone in the population has an opportunity and same freedom to be selected as a sample. ${ }^{8}$ However, in taking sample for in-depth interview, the researcher will use purposive sampling. Purposive sampling method is a sample that is chosen based on the criteria or purpose of the study. In this study, the criteria for in-depth interview respondents are; one from local decision policy and one from a teacher while there are 50 questions in the questionnaire. There are five specific question that talking about financial literacy; financial individual knowledge, investment, insurance, saving and loan, and financial institution knowledge.

In this study, the dependent variable used is a financial literacy, which is a person's ability to process and financial planning, not only for himself but also his family. Then, there are three independent variables used in this study. The first one (1) is gender, this variable explain the gender, i.e. male and female. Second (2) is the educational background, in this variable is determined by the last study respondents were then classified into; SD, SMP, SMA, Diploma, S1, S2 and S3. Variable three (3) or the last one is the revenue, variable describes the amount of a person's income in each month are clarified in the form of average; < 1.000.000, 1.000.000 - 3.000.000, 3.000.000 $5.000 .000,5.000 .000-7.000 .000,>7.000 .000$.

The data has been obtained from the questionnaire, before processing should be performed validity test first to test how valid questions are asked in the questionnaire with the variables studied. ${ }^{9}$ If the validity test is already done, the next step is doing reliability test. Reliability tests are used to test how consistent the answers given by respondents in the questionnaires given. ${ }^{10}$

\footnotetext{
${ }^{8}$ Sumanto, Statistika Terapan (Jakarta: CAPS (Center of Academic Publishing Service), 2014).

${ }^{9}$ Algifari, Analisis Regresi Untuk Bisnis Dan Ekonomi (Yogyakarta: BPFE-Yogyakarta, 2015).

${ }^{10}$ Ibid.
} 


\section{Result and Analysis}

To determine valid or not in research question is using the technique of corrected item correlation. If all the items of variable has a correlation (r) with total score each variables $\geq 0,25$, it can be said valid.

Table 1 Validity Test Result

\begin{tabular}{lcc}
\hline \multicolumn{1}{c}{ Item } & $\begin{array}{c}\text { Corrected Item } \\
\text { Correlation }\end{array}$ & Explanation \\
\hline Financial Individual Knowledge & 0,702 & Valid \\
\hline Investment & 0,402 & Valid \\
\hline Saving and Loan & 0,901 & Valid \\
\hline Insurance & 0,779 & Valid \\
\hline Financial Institution Knowledge & 0,904 & Valid \\
\hline \multicolumn{2}{c}{ Source: Developed for the research } &
\end{tabular}

Based on the data above, it shows that all the variables has corrected item correlation $(r)$ with a total score $\geq 0,25$. Because all the variables has a total score more than 0,25 , it means that all the items can be called valid. But, in Q24 part of saving and loan questions (it can be seen in the appendix), the corrected item correlation ( $\mathrm{r}$ ) is invalid. The Q24 correlation value is 0,144 or less than 0,25 or invalid. So, it can be concluded that validity test in this research is valid with one invalid question, or this research has 49 valid questions and 1 invalid question. The researcher will not delete invalid question because it does not affect to reliability test.

Data can be said reliable if the Cronbach Alpha $\geq 0,70$. If the data value in Cronbach Alpha less than 0,70, it means that the data is unreliable.

Table 2 Reliability Test Result

\begin{tabular}{cc}
\hline Cronbach's Alpha & N of Items \\
\hline 0,938 & 50 \\
\hline Source: Developed for the research
\end{tabular}

Based on the table above, it shows that Cronbach's Alpha value is 0,938 . It can be said that Alpha value between $0,90-0,100$, it means that this research has a high reliable questionare variable. 
After validity and reliablility test, the researcher wil input ordinal data to SPSS and regress it.

Table 3 Case Processing Summary

\begin{tabular}{cc}
\hline Unweighted Cases & $\mathbf{N}$ \\
\hline Selected Cases & 50 \\
$-\quad$ Included in Analysis & 0 \\
$-\quad$ Missing Cases & 50 \\
\hline Unselected Cases &
\end{tabular}

Source: Developed for the research

From the table above, it shows that there is no missing case. It means that there is no passing sample.

Table 4 Dependent Variable Encoding

\section{Original Value}

Internal Value

The awareness of financial literacy is low 0

The Awareness of financial literacy is high 1

\section{Source: Developed for the research}

From the above output table, it describes the result of data input process that is used in dependent variable are the awareness of financial literacy is low with 0 code and the awareness of financial literacy is high with 1 code.

On this interpretation, researcher look at the model worthiness using -2 Log Likelihood value and Chi Square value.

Table 5 Iteration History

\begin{tabular}{llcc}
\hline & & Iteration & $\mathbf{- 2} \mathbf{L o g}$ Likelihood \\
\hline Step & 1 & 30,530 \\
\cline { 2 - 3 } $\mathbf{0}$ & 2 & 28,003 \\
\cline { 2 - 3 } & 3 & 27,878 \\
\cline { 2 - 3 } & 4 & 27,877 \\
\cline { 2 - 3 } & 5 & 27,877 \\
\hline
\end{tabular}

Source: Developed for the research

-2 Log Likelihood value is 27,877 , if it compare with Chi Square value in 0,05 point of significant with $\mathrm{df}$ is $\mathrm{N}-1$. So, $50-1=49$. From Chi Square table, the result is 43,773. So, -2 Log Likelihood < Chi Square $(22,877<$ $43,773)$. If only constans is entered not proper, all the independent variable are 
entered is also not proper, but there is a decreasing in $-2 \log$ Likelihood. The decreasing is $27,877-27,248=0,629$ and significant value is $0,89>0,05$. It can be seen in below table:

Table 6 Omnibus Test of Model Coefficients

\begin{tabular}{llcc}
\hline \multirow{2}{*}{ Step 1} & & Chi Square & Sig. \\
\cline { 2 - 4 } & Step & 0,629 & 0,890 \\
\cline { 2 - 4 } & Block & 0,629 & 0,890 \\
\cline { 2 - 4 } & Model & 0,629 & 0,890 \\
\hline
\end{tabular}

Source: Developed for the research

The percentage of model accuracy in observation classification is 92,0 or $92 \%$. It means from 100 observations, there are 92 observations that accurate in classification by logistic regression model. It can be seen on the table below:

Table 7 Classification Table

\begin{tabular}{lll}
\hline Observed & Persentage Correct \\
\hline Category & $\begin{array}{l}\text { The awareness of financial } \\
\text { literacy is low }\end{array}$ & 4 \\
& $\begin{array}{l}\text { The awareness of financial } \\
\text { literacy is high }\end{array}$ & 46 \\
\hline & 92,0
\end{tabular}

Source: Developed for the research

Table 8 Model Summary Result

\begin{tabular}{ccc}
\hline $\mathbf{- 2}$ Log Likelihood & Cox \& Snell R Square & Nagelkerke R Square \\
\hline $\mathbf{2 7 , 2 4 8}$ & 0,012 & 0,029 \\
\hline
\end{tabular}

Source: Developed for the research

From the table above, the model with taking three independent variables has changing in parameter appraisal (-2 Log Likelihood) is 27,248. In $\mathrm{R}$-square is 0,012 or $12 \%$ (Cox \& Snell) and 0,029 or $29 \%$ (Nagelkerke). It means that three variables; gender, income and education has a high financial literacy awareness that can be explained in $29 \%$. But, remember that this interpretation is only value approach as like as determination coefficient (ordinary linear regression). 
Homer and Lemoshow Test is a test to khow about the model can be said proper or not (goodness of fit), in another word there is no difference between the empirical data and the model. Model can be said proper if the significant value more than 0,05 or -2 Log Likelihood less than Chi Square table.

Table 9 Hosmer and Lemeshow Test Result

\begin{tabular}{c}
\hline Chi Square \\
\hline S,993 \\
\hline \multicolumn{1}{c}{ Source: Developed for the research } \\
\hline $\mathrm{H}_{0}=$ Model has explained clearly ( goodness of fit) \\
$\bullet \mathrm{H}_{1}=$ Model has not explained clearly with criteria if $\mathrm{p}$-value is not \\
significant $(0,701)>0,05)$, it means $\mathrm{H}_{0}$ is accepted. So, the conclusion is \\
model has explained the data clearly (goodness of fit).
\end{tabular}

Table 10 Variable in The Equation

\begin{tabular}{lcr}
\hline & \multicolumn{1}{c}{ Sig. } & $\operatorname{Exp}(\mathbf{B})$ \\
\hline Gender & 0,584 & 1,985 \\
\hline Education & 0,571 & 0,701 \\
\hline Income & 0,911 & 0,895 \\
\hline & Source: Developed for the research
\end{tabular}

Hypotesis nol $\left(\mathrm{H}_{0}\right)$ is rejected if p-value significant $<0,05$. So, if $\mathrm{H}_{0}$ is rejected, the variable can be entered to the model. Based on the table above, $\mathrm{p}$ value significant of gender, income and education $>0,05$. So, $\mathrm{H}_{0}$ is accepted. It means that there is no signigficant affect between gender, income and education to the awareness of financial literacy in Tanjung Putri Village.

All the independent variables are not significant because the study case of the sample is coming from low level society. It can be proven from the average of education background is elementary school and the location of the village itself is remote area.

The last interpretation is odds ratio interpretation. Odds ration is availabe on table 5.10 column $\operatorname{Exp}(\mathrm{B})$. From the table above, the odds ratio interpretation will be:

1. If gender increased by 1 then the awareness of financial literacy tendency become 1,985 fold. 
2. If education background increased by 1 then the awareness of financial literacy tendency become 0,701 fold.

3. If income per-mouth increased by 1 then the awareness of financial literacy tendency become 0,895 fold.

Table 11 Heterokedastisity Test Result

\begin{tabular}{cc}
\hline Model & Sig. \\
\hline Gender & 0,854 \\
\hline Income & 0,987 \\
\hline Education & 0,601 \\
\hline
\end{tabular}

Source: Developed for the research

Output from the table above shows that there is no significant relation between independent variables to absolute residual value, it means that nonheterokedastisity assumption is fulfilled.

Table 12 Multikolinearity Test Result

\begin{tabular}{cc}
\hline Model & VIF \\
\hline Gender & 1,118 \\
\hline Income & 1,122 \\
\hline Education & 1,153 \\
\hline
\end{tabular}

Source: Developed for the research

On the table above, all the VIF value $<10$. So, that assumption model does not contain multikolinearity.

From the questionare data, calculing result of respondent answer is:

1. Responsent who answers very agree $(5)=224 \times 5=1120$

2. Responsent who answers agree (4) $=1160 \times 4=4640$

3. Responsent who answers neutral (3) $=2397 \times 3=7191$

4. Responsent who answers disagree $(2)=1027 \times 2=2054$

5. Responsent who answers very disagree (1) $=192 \times 1=192$

Total questions are 50 questions and the total respondents are 100 respondents. So, $50 \times 100=5000$

Total Skor $=1120+4640+7191+2054+192=15197$

High score for VERY AGREE or VERY GOOD item is $5 \times 5000=$ 25000, while VERY DISAGREE or VERY LESS GOOD item is $1 \times 5000=$ 
5000. So, if respondent total score is 15197 , it means that respondent interpretation value to financial literacy level by index formula percent is: Index $\%$ formula $=$ Total Score $/ \mathrm{Y} \times 100=15197 / 25000 \times 100=60.7 \%=61 \%$. GOOD category. From the data above, it can be concluded that respondent answer to the level of financial literacy is good.

\section{The Influence of Gender to The Awareness of Financial Literacy}

Based on the table 6 , the gender significant value is 0,842 . It means that gender significant value is more that 0,05 . So, gender has no significant affect to the awareness of financial literacy.

On this globalization era, the gap between man and woman is decreasing. Many scholars debate about the link between economic development and women's social in economic and political status. Until now, some feminist still struggle on woman empowerment. The implication is to change the status of women, there needs to be a direct intervention rather than relying solely on economic development to do the job and earn money. ${ }^{11}$

Woman participant has steadily increased even in developing country such as Bangladesh, Indonesia, Malaysia and Pakistan. Principally, there is no distinction in the creation of man and woman. However, different physiological and biological nature, or even patriarchal economic order, leads to different roles in development. Instead of reducing woman participation in development, it suggests differentiating their role. Priority of women's contributions should be given to intergenerational continuity through children's education for the future preparation. Socio-economic problems relating to their involvement in the workforce can be overcome by reducing (not eliminating) either their workload or in general women employment for the sake of future generations. ${ }^{12}$

This research finding is consistent with a research finding from the authors Deerajen Ramasawm, Savila Thapermall, S. Anoop Dowlut and Mootooganaen Ramen. ${ }^{13}$ Gender variable has no significant affect to the awareness level of financial literacy. This finding is not consistent, because there is other research said that gender has a significant affect to the awareness

\footnotetext{
${ }^{11}$ Joshua Eastin and Aseem Prakash, "Economic Development and Gender Equality: Is There a Gender Kuznets Curve?," World Politics 65, no. 1 (January 2013): 156-186.

${ }^{12}$ Muqorobin, "Rethinking Woman Participation in Development."

13 Ramasawmy et al., "A Study of the Level of Awareness of Financial Literacy among Management Undergraduates."
} 
of financial literacy, that reseach is coming from the author Noor Azizah Shaari, Nurfadhilah Abu Hasan, Ramesh Kumar Moona Haji Mohamed, Mior Ahmad Jafri. ${ }^{14}$ Also with a research from Tamilnadhu Region said that financial literacy of marginalized rural women is very low. Development of fiancial literacy would help the women for better financial decision-making and proper utilization of financial services and products. It would help them for wealth accumulation and financial well-being. It will lead to their personal development as well as social development. Their fiancial participation would help our country's economic development.

The explanation about gender equality is about the women empowerment nowadays. Working-women are considered as financially literate and have positive financial attitude. In today's world, women are also consuming financial products and services independently as well as in conjunction with the family members, partner and spouses. This increasing participation of women in financial decision is not astonishing because of the recent revolution in socio-economic level, family, demographics and economic lives of women in the last 50 years. Nevertheless, major portion of working women are still unaware of integrated financial terms and those individuals who understands financial literacy can do better saving, budgeting and control spending; participate in financial integrated markets, can handle debts and other mortgages; retirement planning; and eventually, results in accumulating affluence. Financial literacy and proper financial attitude are essential for financial wellbeing and economic empowerment of individual. Money and effective management of money is crucial for better livelihood and wellbeing ${ }^{15}$.

Now, it is different with women traditionally were primarily responsible for the home and daily maintenance activities, which often include household budgeting and bill paying. Women's lack of knowledge and confidence with regard to money management and investment programs impacts their ability to reach their financial potential. The basic principles of investing are the same across all gender, but women do not look at financial matters in the same way as their counterpart does. Women who are

\footnotetext{
${ }^{14}$ Shaari and Hasan, "FINANCIAL LITERACY: A STUDY AMONG THE UNIVERSITY STUDENTS."

15 Abdul Haque and Mehwish Zulfiqar, "Women's Economic Empowerment through Financial Literacy, Financial Attitude and Financial Wellbeing" 7, no. 3 (2016): 11.
} 
empowered and educated must utilize tools and resources to reach their financial potential. ${ }^{16}$

In Islamic perspective, women employment is among the current issues getting paid special attention, in particular, from women activists, who demand for more liberation in their life. Nevertheless in Islamic perspective, the issues raised are not very clear, since Islam has given a chance for women to express their rights proportionately. Indeed, Islam recognizes numerous differences between man and woman, stemming from their physical and biological differences. These differences necessarily lead to possible differences in their role and contributions to development and national building. Consequently, sexual division of work between man and woman is thus possible for application. This is not meant at discriminating women from men but rather differentiating their duties and responsibilities. ${ }^{17}$

In comparing between this reseach finding and the data that researcher got from depth interview. Average of man who has marriage in Tanjung Putri Village is managing their financial to his wife; a woman (depth interview data from Mr. Dedy, 34 years old, on January 20th, 2017).

\section{The Influence of Income per Month to the Awareness of Financial Literacy}

Based on the table 5.10 , the income significant value is 0,998 . It means that income significant value is more that 0,05 . So, income has no significant affect to the awareness of financial literacy. The income classification are income per-month $<1.000 .000,1.000 .000-3.000 .000,3.000 .000-5.000 .000$, $5.000 .000-7.000 .000$, and $>7.000 .000$; in rupiah's.

The average income per-month of society in Tanjung Putri Village is 1.000.000 - 3.000.000. That average of income is appropriate with District Minimum Wage or UMK (Upah Minimum Kabupaten) in West Kotawaringin. West Kotawaringin UMK in 2016 is Rp 2.204.120, it incerases 10\% from the previous UMK. ${ }^{18}$

\footnotetext{
${ }^{16}$ Bina Agarwal, Gender and Green Governance: The Political Economy of Women's Presence Within and Beyond Community Forestry (New Delhi: Oxford University Press, 2010).

${ }^{17}$ Muqorobin, "Rethinking Woman Participation in Development."

18 "Kabupaten KOTAWARINGIN BARAT | Berita |," accessed December 26, 2019, http://site.kotawaringinbaratkab.go.id/content/6/umk-kobar-naik-85-persen.
} 
This finding is different with another research from the journal by Irma Setyawati and Sugeng Suroso. ${ }^{19}$ The finding on that journal said that income has a significant affect to the awareness of financial literacy. Which is higher income will influence the awareness level of financial literacy, and lower income will make lower level of the awareness of financial literacy. So, the affect is positive significant.

As we know that income also appears to play an important role in people's saving behavior. In the journal by Nurul Shahnaz Mahdzan and Saleh Tabiani ${ }^{20}$ said that when income raising, the saving also increasing, and it will affect to the awareness of financial literacy. It means that income has a significant influence to the awareness of financial literacy. Let take the correlation between this research finding and that journal finding. The journal can say that income rising will increase saving because the people's education background. Increasing saving is one of measurement to measure the awareness of financial literacy. In fact, that opinion is different with this research case.

This research case is in remote area, the average of education background is SD or elementary school. But, even the society in Tanjung Putri Village has a low education background, they have a high income. It can be proven by the income and UMK are equal, even more. The researcher has a data from the interviews, the respondent is a teacher in the elementary school. Her education background is elementary school. She is one of the evidence that income has no significant affect to the awareness of financial literacy in term of this research case, because she has an income more than 3.000.000 and has an insurance for her family health and children education (in-depth interview data from Mrs. Dewi, 45 years old, on January 20th, 2017).

The example above from the in-depth interview data not only talking about one person in the society of Tanjung Putri Village, but also she said that average of society in Tanjung Putri Village do what she does. That statement can be proven from the data in Chapter IV and researcher explanation above about income and UMK in Tanjung Putri Village.

\footnotetext{
19 Irma Setyawati and Sugeng Suroso, "Sharia Financial Literacy and Effect On Social Economic Factors (Survey On Lecturer In Indonesia)" 5, no. 02 (2016): 11.

${ }^{20}$ Nurul Shahnaz Mahdzan and Saleh Tabiani, "THE IMPACT OF FINANCIAL LITERACY ON INDIVIDUAL SAVING: AN EXPLORATORY STUDY IN THE MALAYSIAN CONTEXT" 12, no. 1 (n.d.): 16.
} 


\section{The Influence of Education Background to the Awareness of Financial Literacy}

Based on the table 5.10, the education background significant value is 0,589 . It means that education background significant value is more that 0,05 . So, education background has no significant affect to the awareness of financial literacy. The education background classifications are SD, SMP, SMA, Bachelor and Postgraduate.

This research finding is consistent with a journal by Sandra J. Huston. ${ }^{21}$ That journal said that education background has no significant affect to the awareness of financial literacy. Because, there is no financial education subject in all level of educations. So, the journal indicates that not all financial education programs are equally effective, that factors other than financial literacy contribute to financial distress or both.

The research finding that not significant shows that every people in Tanjung Putri Village with education background SD, SMP, SMA, Bachelor and Postgraduate has same opportunity to get a high awareness of financial literacy. It occurs because the education about financial literacy can be gotten in everywhere, not only in formal education, but also in informal education.

In Indonesia itself, financial literacy education still rare to be found, either in elementary school until university. Curriculum about financial literacy education have not included yet in any school subject. It makes an impact to the lack access in understanding of financial literacy. It is different from our countries which included financial literacy subject to the formal school, such as in Canada, Brazil, and Australia. Person who has a high education background does not guarantee his or her awareness of financial literacy in high understanding. It can be proofed with this research finding, the average of society education background in Tanjung Putri Village is in elementary school (SD), but their awareness of financial education is high.

In another case, there is also a journal written by Sekar.M and Gowri. $\mathrm{M}^{22}$ said that more the education level more is the level of financial literacy, it menas that education background has a significant affect to the awareness of financial literacy. It occurs because of the case study on that research. That research's case study was in Coimbatore, which the city is still contains of gap

\footnotetext{
${ }^{21}$ Sandra J. Huston, “Measuring Financial Literacy,” Journal of Consumer Affairs 44, no. 2 (2010): 296-316.

${ }^{22}$ M Sekar and M Gowri, “A Study on Financial Literacy and Its Determinants among Gen Y Employees in Coimbatore City," Great Lakes Herald 9, no. 1 (2015): 34-45.
} 
of gender, difference level of education and lack of government policy about financial literacy programs. Financial literacy education is not just for investors as well as we know. It is just as important, if not more so, for the average family trying to balance its budget and save for their children's education and the parents' retirement. More needs to be learned about the financial education needs of consumers at various stages in their lives and how financial education programs can be designed to best address there needs.

So, if we look back to our country, Indonesia. Financial literacy programs from the government has been occuring since 2011, for example; integration of financial education in elementary and junior high school curriculum (pilot project), extension of information access (enhancement of BI's website with consumer education and information), and financial education for migrant worker.

\section{The Awareness Level of Financial Literacy in Tanjung Putri Village}

Based on the index formula percent data result, the research finding about the awareness level of financial literacy in Tanjung Putri Village is good at $61 \%$ point. On 2006, there were a lot of moneylenders or creditors in Tanjung Putri Village. There came to the village because the distance of the village to the bank in the city is quite far. There came with a lot of promises to the society, in order to inciting borrow money from them. Society easy to get money in cash with them, but when their want to bringing back the money, the moneylender or creditor offered a high interest until more than half of total ( $>$ $50 \%$ ). In the end, the society got misery because a lot of debts. On that year, the awareness of financial literacy is still low (depth interview data on January 20th, 2017).

On 2006, there was only on the transportation access to Tanjung Putri Village by river. But, year by year, the transportation access to Tanjung Putri can be accessed by shore (using motorbike or car, etc). So, there are many people in Tanjung Putri Village save their money in a bank, even their have to traveled more less 2 hours. The government of Tanjung Putri Village has a vission to financial institution program. Head of the village said that the village government will make a BUMD (Badan Usaha Milik Desa) to the society this year. That BUMD contains of saving, borrowing, and other as like as a cooperative.

Because of the society experience in the past about money lender or creditor, it makes an impact to the awareness of society to financial literacy. 
That opinion has a consistent finding with a research by Catherine Demosthenous, Boni Robertson, Anuja Cabraal and Supriya Singh. ${ }^{23}$ They said that cultural identity influenced financial literacy and shaped money and money management experiences. So, it can be proofed by Tanjung Putri Village society, they more careful when want to borrow a money. They also have several investations to be saved in the future. But, if the researcher asks about stock exchange, they do not know about it yet. Why? Because, there is not signal and electricity yet in Tanjung Putri Village.

Talking about Islamic financial literacy, the society in Tanjung Putri Village still do not know yet about Islamic financial literacy, for example; Islamic Bank, BMT, and other Islamic financial institutions. This ignorance could be one of the suggestions to increase the awareness of Islamic financial literacy as the best way in economic problem. Because, Muslim must seeks to understand Islamic finance because it is a religious duty. If Muslims do not care about the prohibition of riba, maysir and gharar and continue to consume conventional financial products, then the Islamic financial system will never be developed. Perpetuating the conventional financial system is certainly sinful for Muslims.

\section{Conclusion}

Based on the test result and analysis about financial literacy level in remote area with a study case in Tanjung Putri Village, there are some conclusion. First, financial literacy level in Tanjung Putri Village that become a respondent in this research is in good category with an index percentage value at $61 \%$, so it can be concluded that the awareness of financial literacy in Tanjung Putri Village is high. Next, gender has a negative effect to financial literacy level with a significant value is 0,584 at the 5 percent level which happens because there is no gap again between man and woman. If gender increased by 1 then the awareness of financial literacy tendency become 1,985 fold. Then, Income has a negative effect to financial literacy level with a significant value is 0,911 at the 5 percent level. It can be happen because the avarage of society income per-month is equal even more with the UMK in West Kotawaringin Region; $1.000 .000-3.000 .000 \geq 2.204 .120$. If income increased by 1 then the awareness of financial literacy tendency become 0,895 fold. Lastly, Education backgroud has a negative effect to financial literacy

${ }^{23}$ Catherine Demosthenous et al., "Cultural Identity and Financial Literacy: Australian Aboriginal Experiences of Money and Money Management" (n.d.): 18. 
level with a significant value is 0,571 at the 5 percent level. It can happen because there is no financial education subject in any level of education, both formal and informal. So, every people has an opportunity to get a good understanding in financial literacy. If education background increased by 1 then the awareness of financial literacy tendency become 0,701 fold.

The finding of the research for researcher is this new finding said that financial literacy in Tanjung putri Village is good. All the variables are not significant because this research located in the low level society. There is another thing that more important to increase the awareness level of financial literacy to the society besides education, gender, and income, that is an experience.

\section{Bibliography}

Agarwal, Bina. Gender and Green Governance: The Political Economy of Women's Presence Within and Beyond Community Forestry. New Delhi: Oxford University Press, 2010.

Algifari. Analisis Regresi Untuk Bisnis Dan Ekonomi. Yogyakarta: BPFEYogyakarta, 2015.

Demosthenous, Catherine, Boni Robertson, Anuja Cabraal, and Supriya Singh. "Cultural Identity and Financial Literacy: Australian Aboriginal Experiences of Money and Money Management" Financial Literacy, Banking and Identity Conference (2016): 18.

Eastin, Joshua, and Aseem Prakash. "Economic Development and Gender Equality: Is There a Gender Kuznets Curve?" World Politics 65, no. 1 (January 2013): 156-186.

Haque, Abdul, and Mehwish Zulfiqar. "Women's Economic Empowerment through Financial Literacy, Financial Attitude and Financial Wellbeing" 7, no. 3 (2016): 11.

Huston, Sandra J. "Measuring Financial Literacy." Journal of Consumer Affairs 44, no. 2 (2010): 296-316.

Mahadzir, Ahmad. "Why Islamic Financial Literacy Is Important." In Personal Money, Islamic Financial Planning, 48, 2010.

Mahdzan, Nurul Shahnaz, and Saleh Tabiani. "The Impact of Financial Literacy on Individual Saving: An Exploratory Study in the Malaysian Context."'Transformation in Business and Economics 12, no. 1 (2013): 16. 
Ma'ruf, Ahmad, and Tasya Desiyana. "Literasi Keuangan Pelaku Ekonomi Rakyat." Buletin Ekonomi, no. 2 (2015): 8.

Muqorobin, Muqorobin. "Rethinking Woman Participation in Development." IQTIS AD Journal of Islamic Economics (1999): 45-57.

Nasilah, Siti, and Anggia Kargenti Evanurul M. "Integrasi Diri Sebagai Konsep Sehat Mental Orang Melayu Riau." Jurnal Psikologi 11, no. 1 (April 13, 2016): 37-48.

Ramasawmy, Deerajen, Savila Thapermall, S Anoop Dowlut, and Mootooganagen Ramen. "A Study of the Level of Awareness of Financial Literacy among Management Undergraduates" 3rd Asia-Pacific Business Research Conference (2013): 13.

Sekar, M, and M Gowri. "A Study on Financial Literacy and Its Determinants among Gen Y Employees in Coimbatore City." Great Lakes Herald 9, no. 1 (2015): 34-45.

Setyawati, Irma, and Sugeng Suroso. "Sharia Financial Literacy And Effect On Social Economic Factors (Survey On Lecturer In Indonesia)" International Journal of Scientific \& Technology Research 5, no. 02 (2016): 11.

Shaari, Noor Azizah, and Nurfadhilah Abu Hasan. "Financial Literacy: A Study among the University Students"Institute of Interdisciplinary Business Research 5, no. 2 (2013): 21.

Sumanto. Statistika Terapan. Jakarta: CAPS (Center of Academic Publishing Service), 2014.

Thapa, Bharat Singh, and Surendra Raj Nepal. "Financial Literacy in Nepal: A Survey Analysis from College Students." NRB Economic Review 27, no. 1 (2015): 49-74.

"Kabupaten KOTAWARINGIN BARAT | Berita |." Accessed December 26, 2019. http://site.kotawaringinbaratkab.go.id/content/6/umk-kobarnaik-85-persen. 